\title{
EXAMINATION OF REGIONAL DISPARITY IN THE LEVEL OF TOURIST OFFER IN RURAL CLUSTERS OF SERBIA
}

Tamara Gajićl, Aleksandra Vujko², Marko D. Petrović ${ }^{3}$, Milutin Mrkša ${ }^{4}$, Mirjana Penićs

*Corresponding author E-mail: tamara.gajic.1977@gmail.com

\begin{tabular}{ll}
\hline A R T I C L E I N F O & A B S T R A C T \\
Original Article & $\begin{array}{l}\text { Serbia is a country known for turbulent historical events, } \\
\text { which completely disrupted the economic and political } \\
\text { Received: } 16 \text { February 2018 } \\
\text { state of the country, and which had negative effects on } \\
\text { the country's tourist development. In this research, the } \\
\text { accepted: 07 June 2018 }\end{array}$ \\
doi:10.5937/ekoPolj1803911G & $\begin{array}{l}\text { provided in rural parts of Serbia, and on the basis of } \\
\text { the obtained data, found that there are disparities in the } \\
\text { UDC 332.13:338.48-(1-22)(497.11) } \\
\text { Keywords: }\end{array}$ \\
rural clusters, regional & $\begin{array}{l}\text { of the services provided. So far, only a small number of } \\
\text { authors have pointed to this issue, however, this research } \\
\text { discusses a key problem that has negative implications for } \\
\text { the development of rural tourism in Serbia. By including } \\
\text { results in further research related to rural tourism, it is } \\
\text { possible to develop long-term plans for removing regional } \\
\text { disparities in rural clusters in Serbia. }\end{array}$
\end{tabular}

(C) 2018 EA. All rights reserved.

\section{Introduction}

A large number of researches in the world deals with the development of rural tourism and the quality of services provided, which is often a limiting factor of development. Vujko (2017) points out in her research that rural tourism, both in developed and underdeveloped

1 Tamara Gajić, Ph.D., professor of professional studies, Novi Sad School of Business, Vladimira Perića Valtera 4, 21000 Novi Sad, +38163565544, tamara.gajic.1977@gmail.com

2 Aleksandra Vujko, Ph.D., professor of professional studies, Novi Sad School of Business, Vladimira Perića Valtera 4, 21000 Novi Sad, +381649142645, aleksandravujko@yahoo. com, South Ural State University, Institute of Sports, Tourism and Service, (76 Lenin Ave., Chelyabinsk 454080, Russia) ORCID ID (http://orcid.org/0000-0001-8684-4228)

3 Marko D. Petrović, PhD., Researcher, Geographical Institute "Jovan Cvijić", Serbian Academy of Sciences and Arts (SASA), Belgrade, Serbia, E-mail: marko d petrovic@ yahoo.com, South Ural State University, Institute of Sports, Tourism and Service, (76 Lenin Ave., Chelyabinsk 454080, Russia).

4 Milutin Mrkša, PhD., Professor of professional studies, Novi Sad Business School, Str. Vladimira Perica Valtera 4, 21000 Novi Sad, Serbia, E-mail: mmrksa@gmail.com

5 Mirjana Penić, PhD., Researcher, Department of Geography, Tourism and Hotel Menagement, Faculty of Science, University of Novi Sad, Trg Dositeja Obradovića 3, 21000 Novi Sad, Serbia, E-mail: penicns@yahoo.com 
countries, often serves to stimulate regional economic activity. Gajic (2017) proposes that rural areas are perceived for tourists as places of safety, surrounded by open spaces and natural beauty places where everyone is treated with respect and kindness. In the last years of the 20th century, Serbia suffered a very difficult economic and political situation, so even tourism did not take a favorable position on the market. The regional constellation of Serbia is characterized by numerous diversity and a very heterogeneous degree of economic tourism development of rural areas. Rural tourism has been destroyed due to turbulent history, but also failures in rural development support policy, although there are conditions for its intensive development: valuable natural and cultural heritage (relatively preserved in original form), agricultural land, forests and water with rich ecosystems and biodiversity, including significant human resources and economic activities, as well as significant natural, cultural and historical heritage. The revitalization and implementation of rural tourism development is very complex and demanding, especially in the conditions of enormous heterogeneity in the physically small space, as well as economic backwardness of rural areas and the country as a whole. Rural areas of Serbia differ greatly in economic and social terms. This is due to geomorphological, demographic differences, then the difference in economic structures, infrastructure, environmental conditions, transport accessibility. In this paper, the authors presented information on the level of services provided in the regional rural clusters of Serbia, and the aim was to point to the existing regional disparities. Appropriate hypotheses were set up, starting with the research. The authors studied a total of 15 municipalities belonging to clusters: Vojvodina, Southeastern Serbia and Southwestern Serbia. The results achieved with the help of various data analysis analyzes undoubtedly point to the existence of regional imbalances in the level of services provided in rural tourism.

\section{Theoretical framework}

\section{Rural tourism}

Definitions of rural tourism are similar to most theorists, and the differences are made on the basis of the comprehensiveness of the resources listed in them. The term Rural tourism is often associated with historical heritage, authenticity and rusticity, whose development depends on natural environment, arts, heritage and tradition of agrarian societies. Furthermore, it is considered that the development of this form of tourism contributes to economic development and profit making for local communities, as well as to bring great benefits to the tourists themselves, precisely because of the enrichment of knowledge by introducing other cultures, traditions, history and society with the local population (Aref et al, 2009; Khound, 2013). Smith and Eadington (1992) share a similar view that rural tourism is a way to achieve mutual benefit, both for the local population and for tourists, who will enjoy it in natural, social values, which only results in positive effects. Lanea (1994) considers that the concept of rural tourism varies depending on the countries in which it is developing and defined. According to the same authors, rural tourism is identical with the term agrotourism, where the main tourist product is based exclusively on agricultural production and accommodation in traditional farm buildings. 
In addition to the above comparison, authors use the terms green tourism, ecotourism and wilderness or forest tourism, which include different tourism products and services in rural areas. From an economic point of view, rural tourism is seen as an economic sector that opens new jobs for the local population, a higher standard, and the revitalization of rural areas (Svoradova et al, 2013). The development of rural tourism certainly contributes to the following economic categories: GDP growth, unemployment reduction, creating workplaces that do not require special education, stimulate family business, return young people to the village, develop small business - accommodation, catering, trade, entertainment, increasing local residents and state revenues, foreign investment attraction, promotion of the development and variety in other sectors (local crafts, manufacturing and agriculture), infrastructure development (Tosun, 2002). Apart from the economic effects, there are other non-economic effects, but they are no less important for local communities: promotion of cultural heritage and cultural exchange, discovery of new different cultural activities, promotion of social integration, community involvement, conservation and promotion of indigenous cultural values, promotion of local citizens' entrepreneurship, protection of natural areas, improving infrastructure, protection of the landscape.

\section{Meaning of quality service (level of provided services) as a factor of success}

The quality of services in tourism is viewed from the perspective of consumers, or his expectations. By ensuring the continuous and complete quality of the service, the preconditions for achieving customer satisfaction (user services) are set, and in that sense, providing the desired quality for consumers and their satisfaction, they achieve numerous competitive advantages. The concept of quality in tourism enables us to achieve the long-term goals of the company, as well as the satisfaction of the consumers through the delivered value. Many theorists adhere to the fact that success in the tourism market is achieved by adhering to all the principles of achieving quality service and creating loyal consumers (Said et al, 2013). Regarding the development of rural tourism, the development of quality services as a way of attracting consumers (Nair, 2006) is of great importance, and in terms of destinations, it is sure that quality attainment is essential for the success and preservation of the position on the tourist market. Furthermore, it is the customer who decides on whether a service is of quality or not.

Hence, tourists' evaluation of service quality is of prime importance (Lopez- Toro et al, 2010). Achieved quality of the influence affects the tourists themselves, as consumers and their choice of destination, as well as the wish for a return (Huh et al, 2006), and to make recommendations as the best way to promote and attract new consumers (Ozdemir et al, 2012). In recent decades, the construct of service quality and tourist satisfaction continue to receive a lot of research attention in the field of tourism (Narayan et al, 2009). Research is increasingly based on the promotion and achievement of quality services in rural tourism, providing a loyal consumer, and therefore a successful business in the tourism industry and the fight against competition (Knutson et al, 2007; Chen et al, 2011). Quality service becomes a strong link between consumers and service providers, 
but can be achieved only if the customer needs are known in detail. According to Badler (2004), quality service is an important segment of successful business, but it must be recognized on the market and provide survival in the future.

Quality and related services are standard requirements of today's customers, which in the future will be the decision factor for customers. He struggles with competition can only be carried out with a better quality service, and all requests of consumers will be satisfied above the expectations (Oprean et al, 2011; Jose et al, 2015). In past years, customer experience has been a key concept in service research and management, including fields such as services marketing, innovation and retailing (Jakkola et al, 2015). Olsson (2012) also based his research on achieving quality service in tourism development, which affects the loyalty of tourists. The main weapon in the fight against competition is a quality service (Baloglu et al, 2003; Augustyn et al, 2004; Klaus et al, 2013). However, some of the theoreticians argue that a large number of research based on consumer experience is conceptual and descriptive (Chang et al, 2010; Helkkula, 2011) and does not reflect the causal state and impact of experience quality and marketing outcomes (Palmer, 2010; Lemke et al, 2011).

\section{The state of rural development in the EU and Serbia}

In the EU, rural areas cover over $90 \%$ of the territory, with approximately $57 \%$ of the population (average population density of 125 inhabitants per square kilometer in rural areas, 614 in urban areas. In remote or sparsely populated areas (north of Finland), the density is 2 inhabitants/km. Portugal, Spain, Italy, Greece, Finland are countries where high income levels in rural areas are not being achieved and they have a high unemployment rate. Romania and Bulgaria have a total of 7.5 million households with less than 5 ha of land, and most cannot earn enough income for their farm households (EC 2004), and are forced to seek work or supplementary income in other parts of the rural economy. Privatization of agricultural land in some countries has led to the disappearance of cooperatives, while in other cooperatives and commercial farms they are in a large percentage of arable land: Slovakia (76\%), Bulgaria (74\%), Czech Republic (72\%) and Hungary (50\%). Individual farms cover most of the cultivated land in Slovenia (94\%), Latvia (90\%) and Poland (86\%). According to the Pan-European Association of Rural Tourism, there are about 200,000 well-known registered service providers in rural tourism in Europe, with more than two million beds (2008). It is estimated that accommodation in various facilities in rural areas has a direct annual tourism spending of around 12 billion euros. In Serbia, about $85 \%$ of the total territory is classified as rural, with $55 \%$ of the population living in it, accounting for $41 \%$ of the country's GDP. The rural part of Serbia has about 3900 settlements. In rural areas of Serbia there are 1.365.000 households, which makes up 54\% of the total number of households in Serbia. From 1991 to 2002, the number of people in rural areas in Serbia decreased by $3,6 \%$ in relation to the total decline in the population in the country by $1 \%$, while in the period from 2002 to 2011 the number of inhabitants decreased by $311,139(10,9 \%)$. 
In the 1920s, the agrarian exodus followed the process of modernization of agriculture and the trend of urbanization and the victims of local wars, rural Serbia lost a large percentage of the population, especially the young. Unemployment rate in rural areas reaches $21 \%$, while GDP per capita is only $74 \%$ of the national average. Households of up to 3 ha have about 328,000 and make up about 56\% of all households in rural areas. Over 600,000 farms have less than 5 ha of land. The average size of the family farm in Serbia is about 3.7 ha. Private ownership is the dominant form in the ownership structure of 5.4 million hectares of the total agricultural land of Serbia. Of the total arable land, $83.7 \%$ are in private hands. The agricultural population includes over 60 years of age with a lower level of education and a large percentage of dependents over 15 years of age. Unemployment in rural areas reaches as much as $21 \%$. Despite the exodus from rural areas, in Serbia the share of agriculture in employment remained among the highest in Europe, with 33\% of employees in the primary sector, while $75-80 \%$ of active working population in rural areas is included in agriculture. In the structure of rural employment, almost $59 \%$ of rural population in the working age between 15 and 64 have secondary education (three years). In the structure of the rural population older than 15 years, the majority of $39.2 \%$ have a secondary school, 28\% completed only elementary school, and $29 \%$ are not literate and do not have any formal education. Only 4\% of the rural population aged 15 and over completed the faculty. So far, rural tourism is supported by more than 32,000 registered and unregistered beds in rural areas, of which only 10,000 are in rural settlements. Rural tourism, at the moment, directly participates in the Serbian economy with 10.4 billion RSD (Serbian currency). This represents 16\% of the total GDP in the travel and tourism sector in the Republic of Serbia in 2016. The average daily consumption recorded is lower than in other countries and amounts to 1900 RSD per person (15 euros), excluding the costs of accommodation and transportation. It is estimated that in 2016 rural tourism realized 2.7 million nights or $27 \%$ of the total number of tourist nights in the Republic of Serbia. The average occupancy rate of a hotel in a rural accommodation is $4 \%$, and the other accommodation capacities are 21\%. (Master Plan of Sustainable Development of Rural Tourism in Serbia, 2015).

\section{Research methodology}

According to the Master Plan of Sustainable Development of Rural Tourism in Serbia from 2010, 12 clusters of rural tourism (KRT) were defined: 1. KRTG 1: Central Serbia and Western Serbia - KRT1: Golija; KRT2: Zlatar and Zlatibor; KRT3: Kopaonik; KRT 4: Central Serbia; 2. KRTG 2: South Banat and Donje Podunavlje - KRT5: Lower Danube Region; KRT6: South Banat; 3. KRTG 3: Eastern Serbia - KRT7: Sokobanja; KRT 8: Eastern Serbia; KRT9: Southeast; 4. KRTG 4: Vojvodina - KRT10: Fruska Gora; KRT11: Upper Danube Region; KRT12: North. The authors of the paper carried out a survey in Serbia in the rural areas of Vojvodina, Southeastern and Southwestern Serbia, from May to December 2016 in the municipalities of Subotica, Sombor, Novi Sad, Irig, Kovin, Valjevo, Kosjerić, Gornji Milanovac, Knić, Čajetina, Majdanpek, Negotin, Knjaževac, Pirot and Dimitrovgrad (Master Plan of Sustainable Development of Rural Tourism in Serbia). 
Table 1. Hypotheses development

\begin{tabular}{|l|l|}
\hline Objectives of research & Hypotheses (sub-hypotheses) \\
\hline $\begin{array}{l}\text { Objective 1- Existed } \\
\text { level of offered tourist } \\
\text { services in rural clusters } \\
\text { of Serbia }\end{array}$ & $\begin{array}{l}\text { H1 - The satisfaction of tourists, with the content and existing level of the } \\
\text { tourist offer of rural households in Serbia, are statistically significantly } \\
\text { different from the offered quality of service }\end{array}$ \\
\hline $\begin{array}{l}\text { Objective 2- regional } \\
\text { disparity }\end{array}$ & $\begin{array}{l}\text { H2 - The attitudes of tourists on the quality of services are statistically } \\
\text { significantly different from the observed regions. } \\
\text { H2a - There is a statistically significant difference in the quality of services } \\
\text { for the segment of importance across regions. } \\
\text { H2b- There is a statistically significant difference in service quality for the } \\
\text { satisfaction segment. } \\
\text { H2c- The economically weakest region offers the weakest quality of service. }\end{array}$ \\
\hline
\end{tabular}

\section{Methodology procedure and sampling}

A survey taken from the research carried out by Albacete-Saez, Fuentes-Fuentes and Llorens-Montes (2007) and the scale tested in rural areas in Spain was used to explore tourist attitudes. Data processing collected during the survey was performed in the SPSS program version 19.0. The research involved 15 rural locations, and a total of 164 respondents. The research involved $42.7 \%$ of men and $57.3 \%$ of women, the age in most cases ranging from 21 to 60 years $(94.5 \%)$. The highest percentage of respondents are students (42.1\%) and those engaged in tourism $(26.2 \%)$. The survey participants are mostly with a completed secondary school (53\%) and with monthly income of 200 to 600 euros $(50.6 \%)$. When the regional structure of the respondents in question data are as follows: Vojvodina 40.5\%, Southwestern Serbia 31.3\%, Southeastern Serbia 28.2\%.

Table 2. Sample profiles ( $\mathrm{N}=164 ; 100 \%)$

\begin{tabular}{|l|c|c|}
\hline Category & Frequency & Percent (\%) \\
\hline Male & 70 & $42.7 \%$ \\
\hline Female & 94 & $57.3 \%$ \\
\hline \multicolumn{3}{|c|}{ Age } \\
\hline $\mathbf{2 0}$ & 3 & $1.8 \%$ \\
\hline $\mathbf{2 1 - 6 0}$ & 155 & $94.5 \%$ \\
\hline $\mathbf{6 1} \geq$ & 6 & $3.7 \%$ \\
\hline \multicolumn{3}{|c|}{ Occupation } \\
\hline Agriculture & 5 & $3.0 \%$ \\
\hline Tourism & 43 & $26.2 \%$ \\
\hline Craft & 10 & $6.1 \%$ \\
\hline Student & 69 & $42.1 \%$ \\
\hline Other & 37 & $22.6 \%$ \\
\hline \multicolumn{2}{|c|}{ Education } \\
\hline Elementary school & -- & -- \\
\hline Secondary school & 87 & $53.0 \%$ \\
\hline
\end{tabular}




\begin{tabular}{|l|c|c|}
\hline College & 41 & $25.0 \%$ \\
\hline BSc & 36 & $21.95 \%$ \\
\hline \multicolumn{3}{|c|}{ Monthly income } \\
\hline$\leq \mathbf{2 0 0}$ & 53 & $32.2 \%$ \\
\hline $\mathbf{2 0 1 - 6 0 0}$ & 83 & $50.6 \%$ \\
\hline $\mathbf{6 0 1 - 1 0 0 0}$ & 23 & $14.0 \%$ \\
\hline $\mathbf{1 0 0 1 - 2 0 0 0}$ & 3 & $1.82 \%$ \\
\hline $\mathbf{2 0 0 0} \geq$ & 2 & $1.21 \%$ \\
\hline \multicolumn{3}{|c|}{ Region } \\
\hline Vojvodina & 66 & $40.5 \%$ \\
\hline Southwestern Serbia & 51 & $31.3 \%$ \\
\hline Southeastern Serbia & 47 & $28.2 \%$ \\
\hline
\end{tabular}

Source: the authors created based on research

\section{Results and discussion}

According to descriptive indicators, it is noted that the variables "Personal responsibility" are rated by the highest marks from the aspect of importance and aspect of satisfaction from tourists visiting the rural areas of Serbia (the arithmetic meanings are 31.33 and 29.94 respectively). The second and third items of importance are "Material elements" and "Relations with tourists", while these are the reverse order by pleasure. The lowest score was recorded by "Safety" on both scales.

Table 3. Descriptive indicators for the highlights on aspects of the existing level of tourist offer

\begin{tabular}{|c|c|c|c|c|c|c|c|c|c|c|}
\hline & & M & SD & $\mathrm{Me}$ & Q & Min & Max & $\mathrm{s}$ & $\mathrm{K}$ & $\mathrm{N}$ \\
\hline \multirow{7}{*}{ 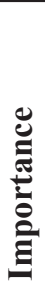 } & Personal responsibility & 31.33 & 3.45 & 32 & 6 & 21.00 & 35.00 & -0.79 & -0.16 & 164 \\
\hline & Supporting offer & 16.74 & 2.61 & 17 & 3.97 & 8.00 & 20.00 & -0.99 & 0.89 & 164 \\
\hline & Relations with tourists & 25.53 & 3.56 & 26 & 4.75 & 13.00 & 30.00 & -0.98 & 0.90 & 164 \\
\hline & Basic requirements & 21.81 & 2.82 & 22 & 4 & 12.00 & 25.31 & -0.81 & 0.15 & 164 \\
\hline & Material elements & 25.59 & 3.05 & 26 & 4 & 17.00 & 30.30 & -0.78 & 0.03 & 164 \\
\hline & Security & 15.90 & 3.14 & 16 & 4.75 & 6.00 & 20.00 & -0.69 & 0.03 & 164 \\
\hline & Empathy & 16.79 & 2.90 & 17 & 4 & 6.00 & 20.00 & -1.04 & 0.89 & 164 \\
\hline \multirow{7}{*}{ } & Personal responsibility & 29.94 & 4.33 & 30.5 & 6 & 17.00 & 35.00 & -0.78 & -0.04 & 164 \\
\hline & Supporting offer & 16.38 & 2.78 & 17 & 5 & 9.00 & 20.00 & -0.55 & -0.50 & 164 \\
\hline & Relations with tourists & 24.98 & 3.43 & 25.5 & 5 & 16.00 & 30.22 & -0.53 & -0.36 & 164 \\
\hline & Basic requirements & 20.11 & 3.74 & 20 & 5 & 9.00 & 25.65 & -0.56 & -0.33 & 164 \\
\hline & Material elements & 24.17 & 3.46 & 25 & 5 & 14.00 & 30.29 & -0.61 & -0.09 & 164 \\
\hline & Security & 14.25 & 3.34 & 14 & 5 & 4.00 & 20.00 & -0.26 & -0.39 & 164 \\
\hline & Empathy & 15.51 & 3.02 & 16 & 5 & 7.00 & 20.00 & -0.34 & -0.64 & 164 \\
\hline
\end{tabular}

Source: Created by the author based on data analysis.

Statistical results show that tourists visiting the rural tourism regions of Serbia are mostly dissatisfied with furniture, space and price of accommodation. Since the possibility of investing in a better tourist offer in Serbia is very limited due to the crisis situation in the country, such a reaction of tourists is expected. Owners of rural households in rural tourism facilities in Serbia are unable to provide higher quality of 
services provided, and this is one of the reasons for underdevelopment of rural tourism in the investigated areas of Serbia. This confirms the hypothesis H1 (+), about the poor level of given services.

A Kruskal-Valis test was applied to compare the ratings of tourists visiting different regions.

Table 4. Results of the Kruskal-Valis test to compare the attitudes of tourists who visited different regions

\begin{tabular}{|c|c|c|c|c|c|c|}
\hline & \multicolumn{3}{|c|}{ Importance } & \multicolumn{3}{|c|}{ Satisfaction } \\
\hline & $\chi^{2}$ & df & $\mathbf{p}$ & $\chi^{2}$ & df & $\mathbf{p}$ \\
\hline $\begin{array}{l}\text { The host fulfills every request in a correct } \\
\text { and timely manner. }\end{array}$ & 5.803 & 2 & 0.055 & 7.094 & 2 & $0.029 *$ \\
\hline $\begin{array}{l}\text { The host knows his job, he is good at him } \\
\text { and does it without error. }\end{array}$ & 3.147 & 2 & 0.207 & 10.586 & 2 & $0.005 * *$ \\
\hline $\begin{array}{l}\text { The host addresses the guests to solve the } \\
\text { problem. }\end{array}$ & 3.104 & 2 & 0.212 & 4.179 & 2 & 0.124 \\
\hline $\begin{array}{l}\text { The host always deals with guest } \\
\text { requirements. }\end{array}$ & 6.368 & 2 & $0.041^{*}$ & 11.22 & 2 & $0.004 * *$ \\
\hline $\begin{array}{l}\text { When a problem arises, the host quickly } \\
\text { approaches his resolution. }\end{array}$ & 7.132 & 2 & $0.028^{*}$ & 5.106 & 2 & 0.078 \\
\hline $\begin{array}{l}\text { The host meets the requirements without } \\
\text { delay. }\end{array}$ & 5.203 & 2 & 0.074 & 8.285 & 2 & $0.016^{*}$ \\
\hline $\begin{array}{l}\text { There is always someone in the household } \\
\text { who is ready to take care of our demands. }\end{array}$ & 0.675 & 2 & 0.714 & 8.573 & 2 & $0.014 *$ \\
\hline The host provides us with quality meals. & 2.347 & 2 & 0.309 & 2.288 & 2 & 0.319 \\
\hline $\begin{array}{l}\text { The host has the role of a tourist guide and } \\
\text { provides us with information about the } \\
\text { services that are available to us. }\end{array}$ & 0.748 & 2 & 0.688 & 1.571 & 2 & 0.456 \\
\hline $\begin{array}{l}\text { The host provides us with homemade and } \\
\text { traditionally prepared meals. }\end{array}$ & 0.609 & 2 & 0.738 & 3.093 & 2 & 0.213 \\
\hline $\begin{array}{l}\text { In the household, there is the possibility } \\
\text { of including guests in domestic activities } \\
\text { (collecting fruits, watching domestic } \\
\text { animals, participating in the preparation of } \\
\text { brandy, wine, home-made food) }\end{array}$ & 0.119 & 2 & 0.942 & 2.719 & 2 & 0.257 \\
\hline $\begin{array}{l}\text { Household members know the tradition, } \\
\text { customs and history of their place. }\end{array}$ & 1.289 & 2 & 0.525 & 9.951 & 2 & $0.007 * *$ \\
\hline $\begin{array}{l}\text { Household members are engaged in } \\
\text { activities that make our stay more complete } \\
\text { (making souvenirs from natural materials, } \\
\text { weaving workshops or connections). }\end{array}$ & 2.544 & 2 & 0.28 & 6.659 & 2 & $0.036^{*}$ \\
\hline $\begin{array}{l}\text { Household members give us good advice } \\
\text { and suggestions about activities that make } \\
\text { our stay more complete. }\end{array}$ & 1.053 & 2 & 0.591 & 5.665 & 2 & 0.059 \\
\hline $\begin{array}{l}\text { Household members provide us with } \\
\text { interesting information about the foods of } \\
\text { the site. }\end{array}$ & 6.032 & 2 & $0.049^{*}$ & 9.571 & 2 & $0.008 * *$ \\
\hline $\begin{array}{l}\text { Household members come to us with } \\
\text { kindness and warmth. }\end{array}$ & 6.737 & 2 & $0.034 *$ & 2.531 & 2 & 0.282 \\
\hline Household members are friendly to us. & 1.625 & 2 & 0.444 & 5.034 & 2 & 0.081 \\
\hline
\end{tabular}




\begin{tabular}{|c|c|c|c|c|c|c|}
\hline & \multicolumn{3}{|c|}{ Importance } & \multicolumn{3}{|c|}{ Satisfaction } \\
\hline & $\chi^{2}$ & df & $\mathbf{p}$ & $\chi^{2}$ & df & $\mathbf{p}$ \\
\hline $\begin{array}{l}\text { Household furniture and furnishings are } \\
\text { well preserved. }\end{array}$ & 2.403 & 2 & 0.301 & 10.45 & 2 & $0.005 * *$ \\
\hline The room we are in (rooms) is comfortable. & 1.944 & 2 & 0.378 & 7.139 & 2 & $0.028^{*}$ \\
\hline $\begin{array}{l}\text { Common rooms in the household } \\
\text { (corridors, kitchen, dining room, lobby) are } \\
\text { well preserved. }\end{array}$ & 2.553 & 2 & 0.279 & 7.027 & 2 & $0.030 *$ \\
\hline Marketing of households is credible. & 1.004 & 2 & 0.605 & 6.925 & 2 & $0.031 *$ \\
\hline $\begin{array}{l}\text { The price of accommodation is in } \\
\text { accordance with quality. }\end{array}$ & 2.676 & 2 & 0.262 & 7.595 & 2 & $0.022 *$ \\
\hline $\begin{array}{l}\text { The interior of the household (furniture, } \\
\text { light, floors, etc.) is pleasant, homely and } \\
\text { authentic. }\end{array}$ & 0.583 & 2 & 0.747 & 5.489 & 2 & 0.064 \\
\hline $\begin{array}{l}\text { The exterior of the household (facade, } \\
\text { garden, yard) is attractive and in keeping } \\
\text { with the rural environment. }\end{array}$ & 0.639 & 2 & 0.726 & 4.452 & 2 & 0.108 \\
\hline The host is dressed in a traditional costume. & 2.338 & 2 & 0.311 & 4.375 & 2 & 0.112 \\
\hline $\begin{array}{l}\text { Rooms in which we are accommodated are } \\
\text { clean. }\end{array}$ & 3.946 & 2 & 0.139 & 18.625 & 2 & $0 * *$ \\
\hline The whole household is clean. & 4.069 & 2 & 0.131 & 22.026 & 2 & $0 * *$ \\
\hline $\begin{array}{l}\text { Extra space (garden, garden, terrace, } \\
\text { barbecue) is clean. }\end{array}$ & 0.028 & 2 & 0.986 & 8.858 & 2 & $0.012 *$ \\
\hline $\begin{array}{l}\text { In the household, security measures have } \\
\text { been taken (eg money deposit boxes, etc.). }\end{array}$ & 1.502 & 2 & 0.472 & 1.992 & 2 & 0.369 \\
\hline The hosts take care of the safety of guests. & 0.583 & 2 & 0.747 & 1.309 & 2 & 0.52 \\
\hline $\begin{array}{l}\text { Each part of the household is marked with } \\
\text { an appropriate sign. }\end{array}$ & 2.321 & 2 & 0.313 & 0.345 & 2 & 0.842 \\
\hline $\begin{array}{l}\text { The access road to the household is marked } \\
\text { with appropriate signs. }\end{array}$ & 0.898 & 2 & 0.638 & 2.086 & 2 & 0.352 \\
\hline The hosts know a foreign language. & 6.461 & 2 & $0.04 *$ & 8.143 & 2 & $0.017 *$ \\
\hline $\begin{array}{l}\text { The hosts try to make sure that the guests } \\
\text { understand them well. }\end{array}$ & 4.073 & 2 & 0.13 & 3.647 & 2 & 0.161 \\
\hline $\begin{array}{l}\text { The hosts take care of the guest taking into } \\
\text { account his personal wishes and needs. }\end{array}$ & 6.317 & 2 & $0.04 *$ & 5.709 & 2 & 0.058 \\
\hline $\begin{array}{l}\text { If there is a group of guests, the host of the } \\
\text { requirements of each of them is accessed } \\
\text { individually. }\end{array}$ & 4.984 & 2 & 0.083 & 3.73 & 2 & 0.155 \\
\hline
\end{tabular}

Source: Created by the author based on data analysis in SPSS 19.0.

Note: $* \mathrm{p}<0.05 ; \mathrm{A} * *$ that is $\mathrm{p}<0.01$ 
Table 5. Comparison of respondents by regions (MWU test) - importance

\begin{tabular}{|c|c|c|c|c|c|c|c|c|c|}
\hline & \multicolumn{3}{|c|}{ Vojvodina - SW Serbia } & \multicolumn{3}{|c|}{ Vojvodina - SE Serbia } & \multicolumn{3}{|c|}{$\begin{array}{c}\text { SW Serbia - SE } \\
\text { Serbia }\end{array}$} \\
\hline & MWU & $\mathrm{Z}$ & $\mathrm{p} / 3$ & MWU & Z & $\mathrm{p} / 3$ & $\begin{array}{l}\text { MW } \\
\mathrm{U}\end{array}$ & $\mathrm{Z}$ & $\mathrm{p} / 3$ \\
\hline $\begin{array}{l}\text { The host always deals } \\
\text { with guest requirements. }\end{array}$ & 1590.5 & -0.58 & 0.18 & 1205.5 & -2.02 & $0.01 *$ & 884.5 & -2.29 & $.007 * *$ \\
\hline $\begin{array}{l}\text { When a roblem } \\
\text { arises, the rost } \\
\text { quickly approaches his } \\
\text { resolution. }\end{array}$ & 1430.5 & -1.64 & $0.03 *$ & 1327.5 & -1.25 & 0.07 & 852 & -2.65 & $.003 * *$ \\
\hline $\begin{array}{l}\text { Household members } \\
\text { provide us with } \\
\text { interesting information } \\
\text { about the foods of the } \\
\text { site. }\end{array}$ & 1272 & -2.39 & $.005^{* *}$ & 1375.5 & -0.88 & 0.12 & 977 & -1.52 & $0.04 *$ \\
\hline $\begin{array}{l}\text { Household members } \\
\text { come to us with } \\
\text { kindness and warmth. }\end{array}$ & 1670.5 & -0.11 & 0.30 & 1237 & -2.22 & $0.01 * *$ & 951 & -2.12 & $0.01 *$ \\
\hline $\begin{array}{l}\text { The hosts know a } \\
\text { foreign language. }\end{array}$ & 1519 & -0.95 & 0.11 & 1103.5 & -2.55 & $.004 * *$ & 973.5 & -1.48 & $0.04 *$ \\
\hline $\begin{array}{l}\text { The hosts take care of } \\
\text { the guest taking into } \\
\text { account his personal } \\
\text { wishes and needs. }\end{array}$ & 1621.5 & -0.39 & 0.23 & 1213 & -2.01 & $0.01 *$ & 884.5 & -2.33 & $.007 * *$ \\
\hline
\end{tabular}

Source: Created by the author based on data analysis in SPSS 19.0.

Note: $* \mathrm{p}<0.05 ; \mathrm{A} * *$ that is $\mathrm{p}<0.01$

According to the MWU significance test, there is a significant difference in the rating of the item "The host always deals with guest requirements". Tourists who visited Southeastern Serbia have lowered this quality indicator according to importance in relation to those from Vojvodina and Southwestern Serbia. According to this statistical result, we conclude that visitors to rural destinations of South East Serbia have lower expectations regarding tourism offer and its quality. This may be partly due to the worsening economic situation and the underdevelopment of this region of Serbia in terms of rural tourism. The highest rating for the item "When a problem arose, the host quickly approaches its resolution" was given by tourists who visited Southwestern Serbia, compared to those from Vojvodina and Southeastern Serbia. This indicator shows that the provider of services in the rural household is demanding and entrepreneurial, and that the biggest expectations for this are due to tourists from Southwestern Serbia. Once again, the analysis leads to the conclusion that the expectations of tourists from this region of Serbia are high and that a high level of quality of the services provided in this area is required. In addition to the susceptibility of the host, there is a statistically significant difference in the expectations regarding the provision of information on traditional foods. The highest rating for the item "Household members provide us with interesting information about the food of a given place" was given by tourists 
from Southwestern Serbia suggesting that they have the highest expectations regarding traditional food which is one of the main attractions of rural tourism.

A statistically significant difference was also found in the item "Household members are going to us with kindness and warmth". The least importance to this item was given by tourists who visited Southeastern Serbia. This is another proof of the low expectations of tourists as a result of poorly developed rural tourism in this region compared to the developed regions of Serbia, such as Vojvodina and Southwestern Serbia. In support of the previously concluded conclusion, the lowest ratings of tourists from South East Serbia that are given with the words "Hosts know a foreign language" and "Hosts take care of the guest, taking into account his personal wishes and needs" can be added. The existence of the difference is statistically significant, and can be attributed to the conclusion that the expectations of tourists from the South-East region are low, and that the rural tourism of this region does not develop in a positive direction.

Table 6. Comparison of respondents by regions (MWU test) - satisfaction

\begin{tabular}{|c|c|c|c|c|c|c|c|c|c|}
\hline & \multicolumn{3}{|c|}{ Vojvodina - SW Serbia } & \multicolumn{3}{|c|}{ Vojvodina - SE Serbia } & \multicolumn{3}{|c|}{ SW Serbia - SE Serbia } \\
\hline & MWU & Z & $\mathrm{p} / 3$ & MWU & Z & $\mathrm{p} / 3$ & $\begin{array}{l}\text { MW } \\
\mathrm{U}\end{array}$ & Z & $\mathrm{p} / 3$ \\
\hline $\begin{array}{l}\text { The host fulfills every } \\
\text { request in a correct } \\
\text { and timely manner. }\end{array}$ & 1316 & -2.26 & $.008 * *$ & 1482 & -0.23 & 0.272 & 873 & -2.44 & $0.005 * *$ \\
\hline $\begin{array}{l}\text { The host knows his } \\
\text { job, he is good at him } \\
\text { and does it without } \\
\text { error. }\end{array}$ & 1539 & -0.88 & 0.125 & 1124 & -2.50 & $.004 * *$ & 782 & -3.04 & $.001 * *$ \\
\hline $\begin{array}{l}\text { The host always } \\
\text { deals with guest } \\
\text { requirements. }\end{array}$ & 1316 & -2.20 & $.009 * *$ & 1305 & -1.33 & 0.060 & 744.5 & -3.32 & $.000 * *$ \\
\hline $\begin{array}{l}\text { The host meets the } \\
\text { requirements without } \\
\text { delay. }\end{array}$ & 1369.5 & -1.86 & $0.021 *$ & 1329.5 & -1.18 & 0.078 & 805 & -2.85 & $.001 * *$ \\
\hline $\begin{array}{l}\text { There is always } \\
\text { someone in the } \\
\text { household who is } \\
\text { ready to take care of } \\
\text { our demands. }\end{array}$ & 1205 & -2.85 & $.001^{* *}$ & 1429.5 & -0.56 & 0.191 & 909.5 & -2.10 & $.012^{*}$ \\
\hline $\begin{array}{l}\text { Household members } \\
\text { know the tradition, } \\
\text { customs and history } \\
\text { of their place. }\end{array}$ & 1413.5 & -1.62 & $.035^{*}$ & 1258 & -1.62 & $.035^{*}$ & 754 & -3.24 & $.000 * *$ \\
\hline
\end{tabular}




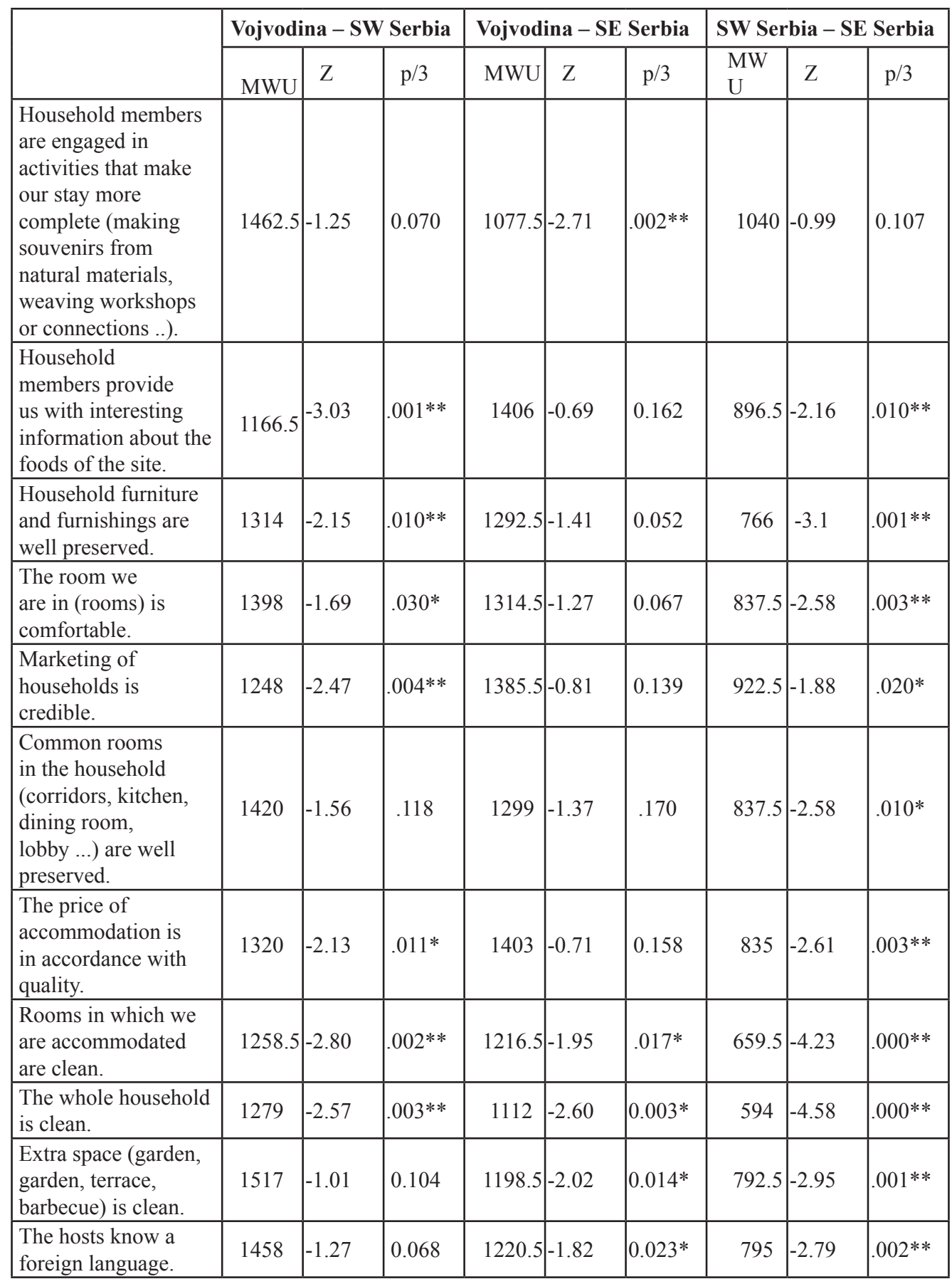

Source: Created by the author based on data analysis in SPSS 19.0.

Note: $* \mathrm{p}<0.05 ; \mathrm{A} * *$ that is $\mathrm{p}<0.01$ 
According to the results of this test and the confirmed statistical significance, it was determined that tourists who visited the rural areas of Southwestern Serbia give the highest grade "The host fulfills every request in a correct and timely manner". Compared with Vojvodina and Southeastern Serbia, we conclude that the highest level of satisfaction was shown by tourists from the south-western part of Serbia, which points to the highest level of quality of tourist services that visitors of rural areas met. The fact is that the southwestern part of Serbia is more developed in terms of rural tourism. However, when assessing the degree of development of this economic activity, the political and economic situation in the country, which is the biggest obstacle to development, must be taken into account. In support of the previous conclusion, the statistical significance of the difference in the assessment of the quality of the host service and the fulfillment of the requirements of the hosts is added, according to the paragraphs "The host knows his job, is good in it and performs it without mistake" and "The host always deals with guest requests". Tourists who visited Southeastern Serbia gave the lowest rating of the quality of the tourist services provided by the host, while the respondents from Southwestern Serbia gave the highest rating to the satisfaction of the host's commitment and dedication to their guests. The high satisfaction of tourists from the south-western parts of Serbia was confirmed by the highest statistical significance for the items "The host is meeting the requirements without delay", "In the household there is always someone who is ready to take care of our demands" and "Household members know the tradition of customs and the history of their place". High satisfaction ratings are the result of a quality service that meets the expectations of tourists. It can be concluded that the Southwestern Serbian hosts are ready to meet the demands of their guests and thus achieve a higher quality of services they are able to provide. The lack of this behavior of the host is noticeable in less developed ruraltourist areas, such as Southeastern Serbia. The conclusion of the conducted analysis confirms that there is a greater dissatisfaction with the quality of the provided services of tourists from the South East municipalities of Serbia. This is confirmed by very low estimates for the following items: "Household members are engaged in activities that make our stay more complete (making souvenirs from natural materials, weaving workshops or connections)", "Additional space (yard, garden, terrace, grill) is clean" , "The hosts know a foreign language" and "Household members provide us with interesting information about the foods of the site".

As the most demanding group in our research, Southwestern Serbia tourists attach great importance to the quality of furniture and premises in the accommodation facility. They expressed great satisfaction with the comfort of accommodation in the rooms, the cleanliness of rooms, and the price they paid for the quality of service provided. Statistical significance was obtained for the following items: "Complete household is clean", "Rooms in which we are located clean", "Common rooms in the household (corridors, kitchen, dining room, lobby) are well preserved", "Price of accommodation Is in keeping with the quality, "" The room we are in (rooms) is comfortable ". Lower estimates for these items were given by tourists who visited rural municipalities of Vojvodina and Southeastern 
Serbia, suggesting that the level of services provided by hosts of these areas to their guests is lower, and that the level of development of rural tourism in these areas compared with the Southwestern Serbia degraded. According to the statistically significant difference in the item "Marketing of households is authentic" of different groups of tourists in Serbia, it can be concluded that the households of Southwestern Serbia are mostly fulfilling the offer that attracted the attention of their guests.

Once again, it was confirmed that a high level of tourist satisfaction points to a better tourist offer of rural catering facilities of Southwestern Serbia in comparison with the offer of the owners of rural households from Vojvodina, and especially from Southeastern Serbia. On the basis of all the results of the survey, hypotheses of $\mathrm{H} 2$, as well as the hypothesis itself, were confirmed. It was found that there is a significant difference in the assessment of the segment's importance $(\mathrm{H} 2 \mathrm{a})$ and satisfaction $(\mathrm{H} 2 \mathrm{~b})$ by regions, and it is also confirmed that the economically weakest cluster is also the least developed tourist $(\mathrm{H} 2 \mathrm{c})$. This fact is a confirmation of the hypothesis $\mathrm{H} 2$, that the regional disparity in the rural development of the development of Serbia is expressed).

\section{Conclusion}

What is primarily based on the topic of this paper is an insight into the existing interregional inequality regarding the quality of existing services in tourism of rural clusters of Serbia. The disparities in the territorial tourism development of Serbia drag the roots of the past, and are mainly conditioned by the polarization of the tourism economy. The basic theory of regional tourism development stems from the fact that development does not happen everywhere and at the same time. The once acquired advantage shows the tendency to sustain it permanently. The driving forces of tourism development trigger the cumulative development process away from other regions that are circumvented. But if it is true that regional development is a dialectical process in which polarization is inevitably and economically justified to a certain degree, then it is a matter of estimation whether the development of the whole tourism economy has reached the point where the effect of expansion is not only from social but also for economic reasons, it gets an edge. In that case, all the factors behind the lagging of tourism development would have to find a solution in a comprehensive regional policy, which would be in opposition to further polarization among the regions. Within such a policy, development goals should be highlighted, which are in fact deeply rooted in tourism and economy and are very simply formulated. They predict that in the process of tourism development all regions are rapidly evolving, and that the differences between each other are gradually reduced, that is, in the outcome, completely disappearing. The authors of the paper tried to point out that the level of services provided to tourists in rural clusters in Serbia is at an unsatisfactory level, and that there are significant unevenness in the quality of services in the investigated areas.

After processing the data, it was confirmed that $\mathrm{H} 1$ and $\mathrm{H} 2$ Hypotheses were confirmed, as well as subhipheses that the items of satisfaction and importance are quite different in clusters, and that the (H2c) economically developed area is also the weakest in terms 
of providing quality services. Regional disproportions are the result of natural and historical conditions of development, the degree of utilization of natural resources, the structure of the economy, the allocation and development of productive forces. Significant differences in the level of quality of services rendered in rural tourism are not only socially unacceptable but become a brake on general development, so increasing attention is focused on achieving more coherent regional development, as conditions for the optimal development of not only individual areas, but Serbia as a whole. Although the goals in some way indicate that under equal development, the level of development and at all costs should not be understood as an average state, it does not foresee the time when these differences could be reduced and, in particular, disappear. There is no vision of the time in which equalization of tourism development should occur in the regions, but the question is how to influence the reduction of large differences in the development of the tourism economy in the regions of Serbia.

\section{Conflict of interests}

The authors declare no conflict of interest.

\section{References}

1. Albacete-Saez, C. A., Fuentes-Fuentes, M. M., \& Llorens-Montes, F. J. (2007). Service quality measurement in rural accommodation. Annals of Tourism Research, 34(1), 45-65.

2. Augustyn, M. M., \& Seakhoa-King, A. (2004). Is the Servqual scale an adequate measure of quality in leisure, tourism and hospitality? Advances in Hospitality and Leisure, 1, 3-24.

3. Badler, H. (2004). Quality Customer Care. Wandsbeck, South Africa, Reach Publishers.

4. Baloglu, S., Pekcan, A., Chen, S., \& Santos, J. (2003). The relationship between destination performance, overall satisfaction and behavioral intention for distinct segments. Journal of Quality Assurance in Hospitality \& Tourism, 4(3/4), 149-165.

5. Chang, T., \& Horng, S., (2010). Conceptualizing and measuring experience quality: the customer's perspective. Service Industry Journal. 30 (14), 24012419.

6. Chen, C. M., Lee, H. T., \& Chen, S. H. Huang, T. H. (2011). Tourist behavioural intentions in relation to service quality and customer satisfaction in Kinmen National Park, Taiwan. International Journal of Tourism Research, 13, 416432.

7. Gajić, T., \& Vujko, A., (2017). Tourism as a potential factor of economic development - A report from Serbia. The Second International Scientific Conference: Tourism in function of development of the republic of Serbia Tourism product as a factor of competitiveness of the Serbian economy and 
experiences of other countries. University of Kragujevac, Faculty of hotel management and tourism in Vrnjačka Banja, 2, 128-144.

8. Huh, J., Uysal, M., \& McCleary, K. (2006). Cultural/heritage destinations: Tourist satisfaction and market segmentation. Journal of Hospitality \& Leisure Marketing, 14(3), 81-99.

9. Helkkula, A., (2011). Characterising the concept of service experience. Journal of Service Management, 22 (3), 367-389.

10. Jakkola, E., Helkkula, A., \& Aarikka-Stenroos, L., (2015). Understanding and advancing service experience co-creation. Journal of Service Management. 26,2 .

11. Jose F. Molina-Azorín, Juan Jos_e Tarí, Jorge Pereira-Moliner, María D. Lopez-Gamero, Eva M. Pertusa-Ortega. (2015). The effects of quality and environmental management on competitive advantage: A mixed methods study in the hotel industry. Tourism Management, 50, 41-54.

12. Khound, J. M. (2013). Constraints and prospects of rural tourism development: An overview of tourism in Shyamgaon of Titabor of Jorhat, District (Assam). Journal of Tourism and HospitalityManagement, 1(1), 27-31.

13. Klaus, P., \& Maklan, S. (2013). Towards a better measure of customer experience. International Journal of Marketing Research, 55 (2), 227-246.

14. Knutson, B., Beck, J., Kim, S., \& Cha, J. (2007). Identifying the dimensions of the ex- perience construct. Journal of Hospitality and Leisure Marketing 15 (3), 31-47.

15. Lanea, B. (1994). What is rural tourism? Journal of Sustainable Tourism, 2(12), 7-21.

16. Lemke, F., Clark, M., \& Wilson, H. (2011). Customer experience quality. An exploration in business and consumer contexts using repertory grid technique. Journal of Acadademic Marketing Sciences, 39, 846-869.

17. Lopez-Toro, A. A., Diaz-Munoz, R., \& Perez-Moreno, S. (2010). An assessment of the quality of a tourist destination: The case of Nerja, Spain. Total Quality Management, 21(3), 269-289.

18. Master Plan of Sustainable Development of Rural Tourism in Serbia, Sustainable Tourism for Rural Development (2011). A joint UN Programme in Serbia, MDGIF Achievement Fund.

19. Nair, A. (2006). Meta-analysis of the relationship between quality management practices and firm performance-implications for quality management theory development. Journal of Operations Management, 24, 948-975.

20. Narayan, B., Rajendren, C., Sai, L. P., \& Gopalan, R. (2009). Dimensions of service quality in tourism - an Indian perspective. Total Quality Management, 20 (1), 61-89. 
21. Olsson, L., Friman, M., Pareigis, J., \& Edvardsson, B. (2012). Measuring service experience: applying the satisfaction with travel scale in public transport. Journal of Retail. Consumer Servvice 19 (19), 413-418.

22. Oprean, C., Tîtu, M., \& Bucur, V. (2011). Managementul global al organizatiei bazate pe cunostinte Editura. AGIR, Bucuresti, 411-420.

23. Ozdemir, B., Aksu, A., Ehtiyar, R., Cizel, B., Cizel, R. B., \& Icigen, E. T. (2012). Relationships among tourist profile, satisfaction and destination loyalty: Examining empirical evidences in Antalya region of Turkey. Journal of Hospitality Marketing \& Management, 21, 506- 540.

24. Palmer, A., (2010). Customer experience management: a critical review of an emerging idea. Journal of Serice Management, 24 (3), 196-208.

25. Said, A., Shuib, A., Ayob, N., \& Yaakob, F. (2013). An evaluation of service quality from visitors' perspectives: The case of Niah NationalPark in Sarawak. International Journal of Business and Society, 14(1), $61-78$.

26. Smith, V. L. \& Eadington R. (1992). Tourism Alternatives: Potentials and Problems in the Development of Tourism, Philadelphia: University of Pennsylvania Press.

27. Svoradova, L., Palkechova, L., \& Viragh, R. (2013). Rural tourism and agrotourism in the Slovak Republic. Conference: 8th International conference on applied business research (ICABR) location: East London, South Africa, 22-26.

28. Tosun, C. (2002). Host perceptions of impacts: A comparative tourism study. Annals of Tourism Research, 29, 231-253.

29. Vujko, A. Plavša J., Petrović, M., Radovanović, M., \& Gajić, T. (2017). Modeling of tourism carrying capacity in the national parks - Fruska gora (Serbia) case study. Open Geosciences, 9, 61-7. 